\title{
Agnostid trilobites from the Upper Ordovician of Sweden and Bornholm, Denmark
}

\author{
PER AHLBERG
}

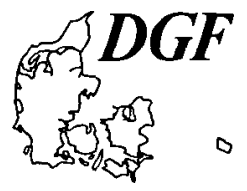

\begin{abstract}
Ahlberg, P.: Agnostid trilobites from the Upper Ordovician of Sweden and Bornholm, Denmark. Bull. geol. Soc. Denmark, Vol. 37, pp. 213-226, Copenhagen, April 10th, 1989.

https://doi.org/10.37570/bgsd-1988-37-17

Arthrorhachis tarda (Barrande, 1846) and Sphaeragnostus cingulatus (Olin, 1906) are described from the Upper Ordovician (Harjuan Series) of Sweden and Bornholm, Denmark. S. cingulatus is extremely rare, while $A$. tarda is generally abundant in middle Ashgillian strata and known from a great number of localities in southem and south-central Scandinavia. Outside Scandinavia, $A$. tarda is frequently encountered in the pre-Hirnantian Ashgill of Poland, Bohemia, various parts of the British Isles, and Kazakhstan. In most of these areas, the species is generally confined to mudstone sequences, and it is usually associated with faunas of Mediterranean type. The generic concept of Sphaeragnostus is revised.
\end{abstract}

Per Ahlberg, Department of Historical Geology and Palaeontology, Sölvegatan 13 S-223 62, Lund, Sweden. October 30th, 1988.

Although the agnostid trilobites reached their maximum diversity during the Middle Cambrian and early Late Cambrian, they are characteristic elements of many Ordovician shelly faunas, and range upwards into the pre-Hirnantian Ashgill. In the Upper Ordovician, agnostid trilobites are generally rare and of low taxonomic diversity. However, in certain beds they may be comparatively common, and Upper Ordovician agnostids are now known from many parts of the world.

Agnostid trilobites have been known from Upper Ordovician rocks of Scandinavia since the middle of the nineteenth century, when Angelin (1851) described Agnostus glabratus. Subsequently, Linnarsson (1869) recognized Agnostus trinodus Salter (= Arthrorhachis tarda) from the Upper Ordovician of Västergötland, south-central Sweden, and placed $A$. glabratus in its synonymy. Later Olin (1906) described $A$. trinodus (= Arthrorhachis tarda) and $A$. cingulatus (= Sphaeragnostus cingulatus) from the Upper Ordovician of Scania (Skåne), southern Sweden. However, Scandinavian material of Upper Ordovician agnostids has received relatively little attention since 1906. This study includes an examination of available museum material, and aims at revising the Upper Ordovician (Harjuan) agnostids of Sweden and Bornholm, Denmark.

Epicontinental Upper Ordovician rocks crop out in several areas in Baltoscandia east and southeast of the Caledonian Front. An exhaustive review of previous works dealing with the stratigraphy of the Upper Ordovician (Harjuan) sequences of the mainland of Sweden was given by Jaanusson (1963), who also introduced the litho- and chronostratigraphical classification currently in use (Fig. 1). Recently, the existing information on the Upper Ordovician in Dalarna and Västergötland was summarized by Jaanusson (in Bruton \& Williams 1982), and Bergström (in Bruton \& Williams 1982) synthesized the stratigraphy and faunas of the Upper Ordovician in Scania. The sequence on Bornholm was briefly described by Gravesen \& Bjerreskov (1982).

\section{Systematic palaeontology}

Terminology. - The terms used in the descriptions are those advocated by Robison (1982), except that rhachis and dorsal furrow are preferred to axis and axial furrow.

Measurements. - Measurements were made with a micrometer eyepiece fitted in a binocular microscope. The following symbols have been used for the measured parameters: $L c=$ maximum 


\begin{tabular}{|c|c|c|c|c|}
\hline $\begin{array}{c}\text { Baltoscandian } \\
\text { Stages }\end{array}$ & Scania & \begin{tabular}{c|c}
\multicolumn{2}{c}{ Västergötland } \\
Kinnekulle & $\begin{array}{l}\text { Billingen- } \\
\text { Falbygden }\end{array}$
\end{tabular} & Östergötland & $\begin{array}{c}\text { Siljan district } \\
\text { Dalarna }\end{array}$ \\
\hline Hirnantian & Tommarp Mudstone & Tommarp Beds & Tommarp Beds & $\begin{array}{l}\text { Tommarp } \\
\text { Mudstone }\end{array}$ \\
\hline \multirow{3}{*}{ Jerrestadian } & \multirow[t]{3}{*}{$\begin{array}{l}\text { Ely } \\
\text { EIIf } \\
\text { Mudrestad } \\
\text { Mudstone }\end{array}$} & $\begin{array}{c}\text { Upper } \\
\text { Jonstorp }\end{array}$ & $\begin{array}{l}\text { Upper } \\
\text { Jonstorp Fm }\end{array}$ & $\begin{array}{l}\text { Upper } \\
\text { Jonstorp }\end{array}$ \\
\hline & & Öglunda Lst & Öglunda Lst & Öglunda \\
\hline & & Lower Jonstorp & $\begin{array}{l}\text { Lower } \\
\text { Jonstorp Fm }\end{array}$ & $\begin{array}{l}\text { Lower } \\
\text { Jonstorp }\end{array}$ \\
\hline Vasaqaardian & ¿UIJIII Dicello- & $\begin{array}{c}\text { Fjäcka } \\
\text { Shale }\end{array}$ & Fjäcka Shale & Fjäcka Shale \\
\hline & 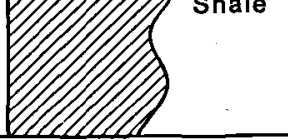 & 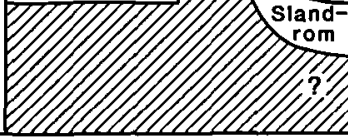 & 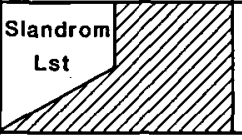 & Slandrom Lst \\
\hline
\end{tabular}

Fig. 1. Stratigraphical subdivision of the Upper Ordovician (Harjuan Series) in Scania, Västergötland, Östergötland and Dalarna. Compiled after Jaanusson (1963, in Bruton \& Williams 1982), Bergström (in Bruton \& Williams 1982) and Holmer (1986).

length (sag.) of cephalon; Lbc = length (sag.) of cephalic border (incl. border furrow); Lac = length (sag.) of cephalic acrolobe; $\mathrm{G}=$ length (sag.) of glabella; $\mathrm{N}=$ distance (sag.) from rear of glabella to highest point of median node; Wc $=$ maximum width (tr.) of cephalon; $\mathrm{Wg}=$ maximum width (tr.) of glabella; Lp1 = maximum length (sag.) of pygidium, incl. articulating halfring; Lp2 = length (sag.) of pygidium, excl. articulating half-ring; $\mathrm{Lr}=$ length (sag.) of pygidial rhachis, excl. articulating half-ring; Lbp = length (sag.) of the posterior pygidial border (incl. border furrow); $\mathrm{Wp}=$ maximum width (tr.) of pygidium; $\mathrm{Wr}=$ maximum width (tr.) of pygidial rhachis.

Repositories. - Illustrated specimens are deposited in the type collections of the Palaeontological Institute, University of Lund (LO), the Swedish Museum of Natural History, Stockholm (RM), the Geological Survey of Sweden (Sveriges geologiska undersökning, Uppsala, SGU), and the Geological Museum of the University of Copenhagen (MGUH).

Family Metagnostidae Jaekel, 1909

Genus Arthrorhachis Hawle \& Corda, 1847.

Type species. - Battus tardus Barrande, 1846 from the Kraluv Dvuir Formation (Ashgill) of
Libomyšl, near Zdice, Czechoslovakia.

Remarks. - I follow Fortey (1980) in restricting the genus Trinodus to the holotype of the type species, T. agnostiformis M'Coy, 1846.

Arthrorhachis tarda (Barrande, 1846)

Figs. 2A-I, 3A-B and 4A-I

1846 Battus tardus. Barr. - Barrande, p. 35.

1847 Arthrorhachis tarda, nob. - Hawle \& Corda, p. 115, pl. 6, fig. 60.

1851 Trinodus agnostiformis (M'Coy) M'Coy, p. 141, pl. 1E, fig. 10.

1851 Trinodus tardus? (Bar. Sp.) - M'Coy, p. 142, pl. 1E, fig. 9.

1851 Agnostus glabratus. n.sp. - Angelin, p. 6 , pl. 6, fig. 5 .

1852 Agnostus tardus. Barr. - Barrande, pp. 913-914, pl. 49, figs. 1-4.

1864 Agnostus trinodus - Salter, pp. 8-9, pl. 1 , figs. 8-10.

1869 Agnostus trinodus Salt - Linnarsson p. 83 , pl. 2, fig. 62 .

1896 Agnostus cf. galba, Billings - Reed, pp. 408-409.

1903 Agnostus agnostiformis (M'Coy), 1846 - Reed, pp. 3-4, pl. 1, fig. 1.

?1903 Agnostus tardus, Barrande, 1846 Reed, pp. 7-8, pl. 1, figs. 8-9. 


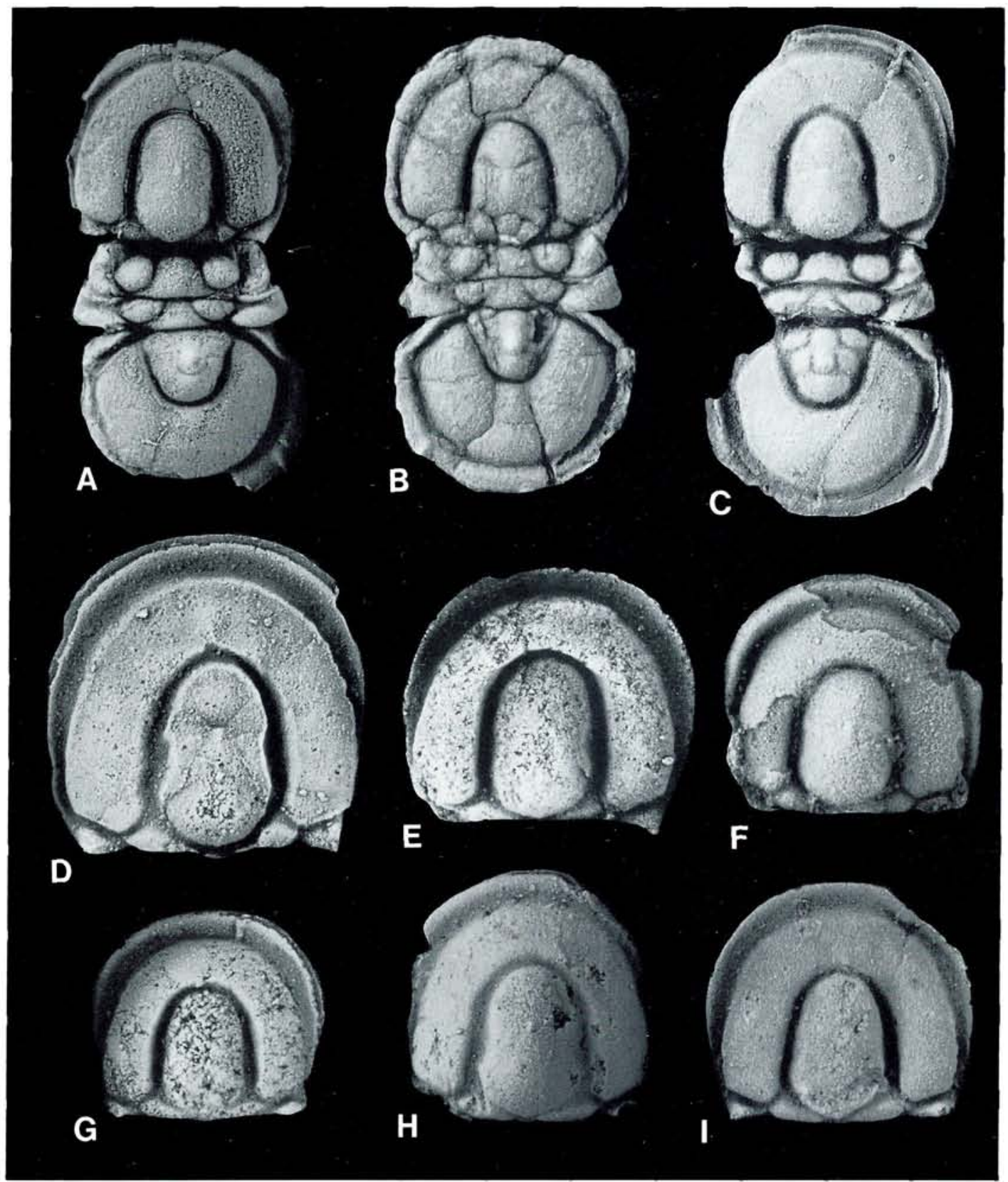

Fig. 2. Arthrorhachis tarda (Barrande, 1846). A, a nearly complete specimen from Röstånga, Scania. Jerrestad Mudstone. Coll. S. A Tullberg 1879. SGU Type 7885. ×8.8. B, a strongly flattened but nearly complete specimen from Bestorp, Mösseberg, Västergötland. Upper Jonstorp Formation. RM Ar 13666. ×7.9. C, internal mould of a nearly complete specimen from Bestorp, Mösseberg, Västergötland. Upper Jonstorp Formation. Coll. excursion 1980. LO 5923t. ×7.1. D, internal mould of a flattened and slightly distorted cephalon from Kungslena, Varvsberget, Västergötland. Upper Jonstorp Formation. RM Ar 6129. × 10. E, internal mould of a flattened cephalon from Kungslena, Varvsberget, Västergötland, Upper Jonstorp Formation. RM Ar 13650. × 10.3. F, partially exfoliated cephalon from Kungslena, Varvsberget, Västergötland. Upper Jonstorp Formation. Coll. N. P. Angelin. RM Ar 13644. $\times 11.9$. G, internal mould of a slightly flattened cephalon from Kungslena, Varvsberget, Västergötland. Upper Jonstorp Formation. RM Ar 6112. × 10.9. H, a nearly complete cephalon from Rustsäter, Kinnekulle, Västergötland. Probably Oglunda Limestone. RM Ar 13664. $\times 10.8$. I, internal mould of a flattened cephalon from Kungslena, Varvsberget, Västergötland. Upper Jonstorp Formation. $\operatorname{RM} \operatorname{Ar} 6110 . \times 10.5$. 

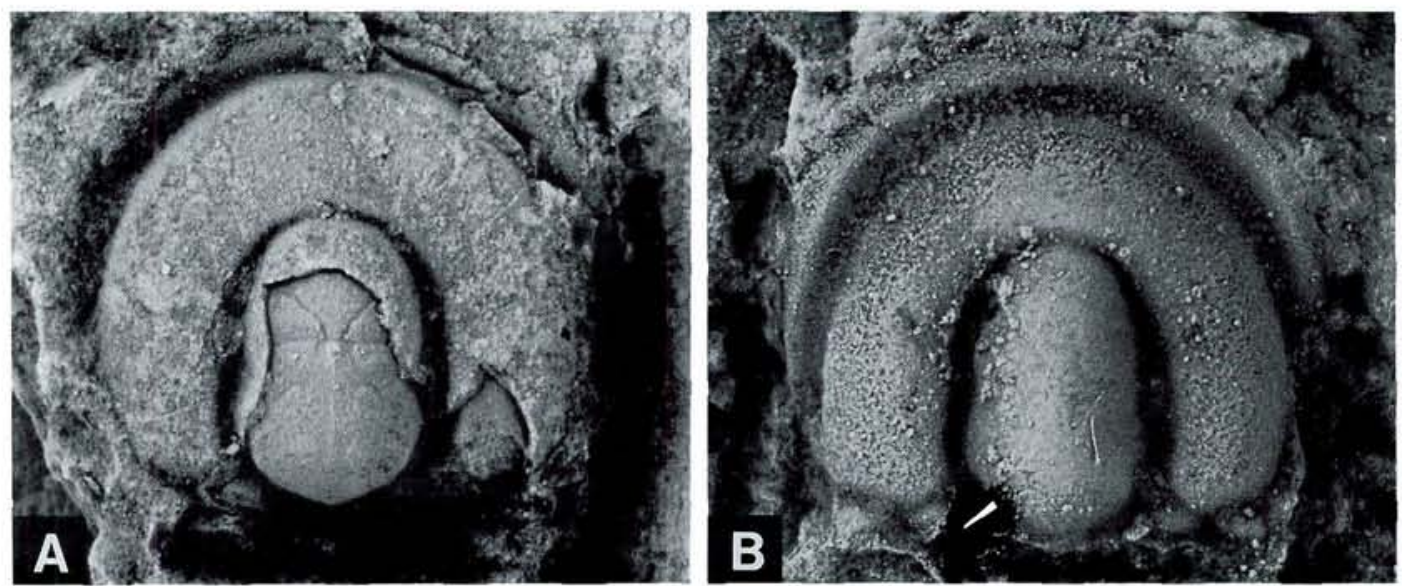

Fig. 3. Arthrorhachis tarda (Barrande, 1846). A, large cephalon, partially exfoliated. Note the presence of glabellar muscle insertion areas. Jerrestad Mudstone, Koängen core (depth 12.12-12.19 m), Scania. LO 5924t. $\times 10.6$. B, a large, nearly complete cephalon from Kungslena, Varvsberget, Västergötland. Upper Jonstorp Formation. RM Ar 6127. ×11.1.

1906 Agnostus trinodus Salt. - Olin, p. 72, pl. 4, figs. $15-16$.

1922 Agnostus tardus Barrande - Koliha, p. 5 , fig. 3 .

1950 Trinodus tarda (Hawle and Corda) Whittington, p. 535 , pl. 68 , figs. $4-6$.

1956 Trinodus tardus (Hawle \& Corda) Kielan, p. 258, pl. 1, figs. 4-6.

1960 Trinodus tardus (Barrande, 1846) Kielan, pp. 59-62, text-fig. 13, pl. 1, figs. 6-13.

?1960 Trinodus sp. - Kielan, p. 62, text-fig. 14 , pl. 1, fig. 5 .

1968 Trinodus tardus (Barrande, 1846) Whittington, p. 97, pl. 24, figs. 8, 10-12, 14-17.

1970 Trinodus tardus (Barrande, 1846) Ingham, pp. 9-10, pl. 1, figs. 1-3.

1971 Trinodus cf. tardus (Barrande) - Dean, pp. 7-8, pl. 1, figs. 3-14.

1971 Trinodus tardus (Barrande) - Dean, p. 8, pl. 1, figs. 1-2.

?1972 Trinodus aff. tardus (Barrande) - Abdullaev, pp. 106-107, pl. 44, fig. 6 .

1974 Trinodus tardus (Barrande), 1846 Apollonov, pp. 8-11, pl. 1, figs. 1-9.

1977 Trinodus tardus (Barrande, 1846) Pek, pp. 25-26, text-fig. 7, pl. 8, figs. 1-4.

aff. 1979 Trinodus aff. tardus (Barrande, 1846) Bruton \& Owen, figs. 2B, 4, 6.

aff. 1980 Trinodus aff. tardus (Barrande, 1846) Owen \& Bruton, p. 11, pl. 1, figs. 1-4.
1981 Arthrorhachis cf. tarda Hawle \& Corda, 1847 - Owen, p. 11, pl. 1, figs. 1-3.

1983 Arthrorhachis tarda - Snajdr, pp. 197198, pl. 7, fig. 3 .

Lectotype. - An internal mould of a nearly complete specimen, illustrated by Barrande (1852, pl. 49, figs. 1-2) and Pek (1977, pl. 8, fig. 2); selected by Přibyl (in Horný \& Bastl 1970). It is deposited in the type collections of the National Museum, Museum of Natural History, Prague, as No. ČD 1812.

Material. - Four complete, articulated specimens, about 100 cephala, nearly 100 pygidia, and several thoracic tergites. The specimens are generally flattened, and preserved as internal or external moulds.

Description. - The cephalon is moderately convex, subquadratic to subcircular in outline, and slightly wider than long (generally 1.1 times as wide as it is long). The glabella, occupying $57-67 \%$ of the total cephalic length, is moderately convex, nearly parallel-sided to gently tapered forward, rounded anteriorly, and well defined by deeply impressed dorsal furrows. It is faintly constricted at about mid-length. A faint median node is generally present and situated slightly anterior to the midpoint of the glabella. In dorsal view, the rear of the glabella is obtusely 
Table 1. Dimensions (in mm) of cephala of Arthrorhachis tarda.

\begin{tabular}{|c|c|c|c|c|c|c|c|}
\hline & Lc & Lbc & Lac & $\mathrm{G}$ & Wc & $\mathrm{Wg}$ & $\mathbf{N}$ \\
\hline RM Ar 6112 & 2.8 & 0.3 & 2.5 & 1.8 & 3.2 & 1.2 & - \\
\hline RM Ar 13644 & 2.9 & 0.3 & 2.6 & 1.7 & 3.2 & 1.1 & 1.0 \\
\hline RM Ar 6110 & 3.3 & 0.3 & 3.0 & 1.9 & 3.6 & 1.2 & - \\
\hline SGU Type 7885 & 3.3 & 0.3 & 3.0 & 2.2 & 3.7 & 1.3 & 1.3 \\
\hline RM Ar 13656 & 3.5 & 0.4 & 3.1 & 2.2 & 4.0 & 1.2 & - \\
\hline RM Ar 13650 & 3.5 & 0.4 & 3.1 & 2.3 & 4.2 & 1.3 & - \\
\hline LO 1979t & 3.6 & 0.3 & 3.3 & 2.3 & 3.8 & 1.3 & - \\
\hline $\operatorname{RM}$ Ar 13666 & 3.8 & 0.4 & 3.4 & 2.4 & 4.6 & 1.5 & - \\
\hline LO $5923 \mathrm{t}$ & 4.3 & 0.4 & 3.9 & 2.4 & 4.7 & 1.5 & 1.4 \\
\hline LO $5924 t$ & 4.7 & 0.5 & 4.2 & 2.8 & 5.1 & 1.7 & 1.5 \\
\hline RM Ar 6127 & 4.7 & 0.5 & 4.2 & 2.7 & 5.0 & 1.6 & - \\
\hline RM Ar 13658 & 4.7 & 0.5 & 4.2 & 2.7 & 5.1 & 1.4 & 1.6 \\
\hline
\end{tabular}

angulate. Rare specimens exhibit the glabellar muscle insertion areas (Fig. 3A). The arrangement and outline of these areas seem to be of typical Arthrorhachis/Geragnostus type (see Fortey 1980, fig. 4A). Glabellar furrows are not apparent. The basal lobes are entire, subtriangular, wider than long, and connected medially. The basal furrows are distinct.

The acrolobe is evenly rounded. The genae are smooth, subequal in width anteriorly and laterally, and slope downwards. The border is wide, convex, and separated from the genae by a deeply incised border furrow. It is widest anteriorly and antero-laterally, becoming narrower postero-laterally. Sagittally, the border and border furrow combined occupy $\mathbf{9 - 1 1 \%}$ of the total cephalic length. Postero-laterally, the border is not tucked beneath the genae. The posterior border is convex (exsag.), defined by a deep border furrow, and protrudes into a short postero-lateral spine. It slopes down beyond the fulcrum and is then curved forward to become the lateral border.

The thorax is of typical Arthrorhachis/Geragnostus type (see e.g. Jaekel 1909; Whittington 1963, fig. 3; Hunt 1967, pl. 22, figs. 19-22, 46).
The pygidium is moderately convex, subcircular to subquadratic in outline, and wider than long (generally 1.2 times as wide as it is long). The pygidial rhachis (excluding the articulating half-ring), occupying $35-42 \%$ of the total pygidial length, tapers backwards and is divided into three distinct lobes. The anterior rhachial lobe (M1) is slightly shorter (exsag.) than the middle lobe (M2), and both are crossed by a prominent median ridge, which is highest posteriorly. M1 is widest (tr.) and occupies $33-40 \%$ of the maximum width of the pygidium. M1 and $\mathrm{M} 2$ are separated from each other by a furrow which is directed inward and slightly forward from the dorsal furrow. The furrow is distinct laterally, but absent medially across the median ridge. The posterior lobe (M3) is generally rounded posteriorly and slightly shorter than M1 and M2 combined. It is separated from M2 by a transverse furrow which is curved slightly forward medially. In some specimens, the posterior lobe is truncate posteriorly with a median protuberance faintly outlined (Figs. 4C and 4F). The pleural fields are smooth, down-sloping, widest sagittally, and set off from the rhachis by deeply incised dorsal furrows. The border is convex, widest posteriorly

Table 2. Dimensions (in $\mathrm{mm}$ ) of pygidia of Arthrorhachis tarda.

\begin{tabular}{lcccccc}
\hline & Lp1 & Lp2 & Lr & Lbp & Wp & Wr \\
\hline LO 5929t & 1.6 & 1.4 & 0.7 & 0.2 & 1.7 & 0.5 \\
SGU Type 7885 & - & 2.8 & 1.1 & 0.4 & 3.5 & 1.4 \\
RM Ar 13657 & 3.5 & 3.2 & 1.5 & 0.4 & 4.0 & - \\
RM Ar 13666 & 3.7 & 3.5 & 1.3 & 0.5 & 4.5 & 1.6 \\
RM Ar 6122 & 4.0 & 3.7 & 1.5 & 0.6 & $4.6 ?$ & 1.7 \\
LO 5923t & 4.2 & 3.8 & 1.5 & 0.6 & 4.8 & 1.6 \\
LO 1980t & 4.6 & 4.3 & 1.7 & 0.6 & 5.5 & 1.9 \\
\hline
\end{tabular}


and postero-laterally, and defined by a deeply impressed border furrow. Postero-laterally there is a pair of spines commencing on a transverse line passing the posterior part of the pleural field. The spines project from the upper surface of the border. The anterior border is narrow (exsag.) and set off from the pleural field by a deeply incised furrow. The articulating facets are prominent and steeply downward-sloping.

The external exoskeletal surface bears a reticulate pattern of raised lines (Figs. $4 \mathrm{C}$ and $4 \mathrm{~F}$ ).

The dimensions of the species are given in tables 1 and 2.

Remarks. - Arthrorhachis tarda seems to be a variable species, particularly with regard to the relative length of the glabella and the pygidial rhachis, and the expression of the median glabellar node. Much of the observed variation is, however, due to the state of preservation with or without the exoskeleton and to the degree of compaction. For instance, compaction and flattening may cause the glabella and the pygidial rhachis to appear proportionately shorter (sag.) in dorsal view. Furthermore, in specimens retaining their original convexity, the border is almost tucked beneath the genae postero-laterally, whereas flattening may cause the lateral border to appear slightly wider in dorsal view.

The Scandinavian material of Arthrorhachis tarda agrees in all important respects with material from the Králův Dvůr Formation of Bohemia (see e.g. Whittington 1950; Pek 1977) and abundant material of the species from the Staurocephalus clavifrons Zone of Poland (Kielan 1960). Similarly to the Scandinavian material, the specimens from Bohemia and Poland are generally preserved as internal or external moulds in mudstones. Slight differences in the relative length of the pygidial rhachis and the length/ width ratio of the cephalon and pygidium can be attributed to intraspecific morphological variability and to tectonic distortion. According to Pek's (1977, text-fig. 7) and Kielan's (1960, text-fig. 13) line drawings of $A$. tarda, the postero-lateral corners of the cephalon lack a spine. Scandinavian material of the species shows, however, that the posterior border protrudes into a distinct postero-lateral spine. This is also obvious in a specimen from Bohemia illustrated by Pek (1977, pl. 8 , fig. 3 ). The spines, however, are rarely pre- served or else are hidden in the rock and difficult to prepare (cf. Apollonov 1974:9).

Specimens of Arthrorhachis tarda from Ashgill units in eastern Ireland (Dean 1971), Wales (Whittington 1968; Dean 1971) and northern England (Ingham 1970; Dean 1971) are closely comparable to Bohemian, Polish and Scandinavian material of the species. However, as noted by Dean (1971:7), they differ in having a slightly longer glabella and pygidial rhachis. It must be emphasized, however, that the British specimens generally seem to retain their original convexity (see e.g. Whittington 1968, pl. 24, fig. 8; Dean 1971, pl. 1, figs. 4, 6, 9, 10), and, as noted above, this fact may cause the glabella and pygidial rhachis to appear longer. In addition, the relative length of especially the pygidial thachis is a variable feature in many agnostids, even within some populations. The cephalic postero-lateral spines of $A$. tarda are clearly seen in a specimen from the Kildare Limestone of Ireland, illustrated by Dean (1971, pl. 1, figs. 7, 11).

Owen (1981, pl. 1, figs. 1-3) illustrated a cephalon and a pygidium from the Ashgillian succession of the Oslo Region, Norway. Although poorly preserved they appear to represent $A r$ throrhachis tarda. On the other hand, agnostid specimens from strata correlative with the upper Caradoc (Upper Chasmops Limestone and uppermost part of the Solvang Formation) in the Oslo Region (Owen \& Bruton 1980:11, pl. 1, figs. 1-4) seem to be distinct from $A$. tarda in having an appreciably longer and wider pygidial rhachis (incl. the art. half-ring it occupies $55 \%$ and $45 \%$ of the pygidial length and width, respectively). The proportions of the individual parts of the pygidium of the upper Caradocian specimens correspond well with $A$. elspethi Raymond, 1925 from the Llandeilo-lower Caradoc of the Southern Appalachians. The cephalon differs, however, from those of $A$. elspethi in being proportionately narrower (tr.), and in having a shorter glabella and shallower dorsal furrows.

A pygidium from the Ashgill of Bukantau, Uzbekistan, referred to as Trinodus aff. tardus by Abdullaev (1972), appears to fall within the range of variation seen in Arthrorhachis tarda. However, its poor state of preservation does not allow a definite assignment to the species.

As noted by Zhou (1987:26), Arthrorhachis sinensis (Sheng, 1964) and other closely allied 

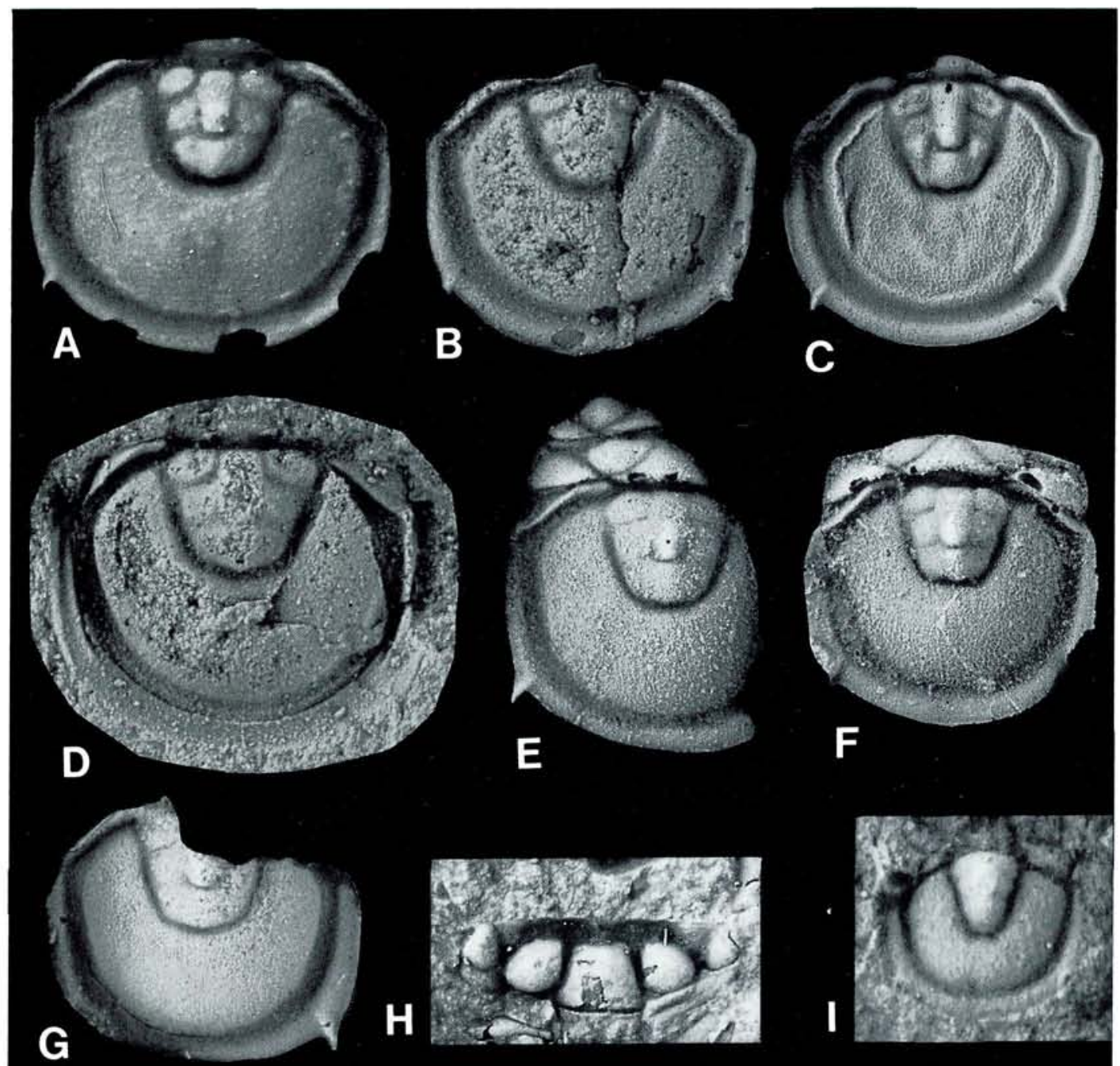

H
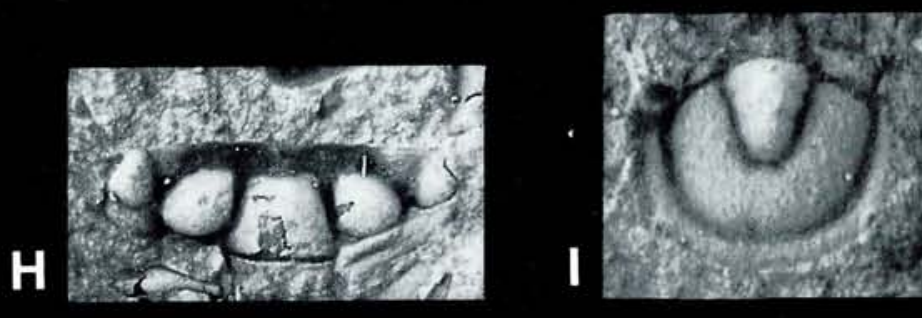

Fig. 4. Arthrorhachis tarda (Barrande, 1846). A, internal mould of a flattened pygidium from Koãngen in the Fågelsång area east of Lund, Scania. Jerrestad Mudstone. Figured by Olin (1906, pl. 4, fig. 16). Coll. E. Olin 1899. LO 1980t. ×8.9. B, internal mould of a flattened pygidium from Kungslena, Varvsberget, Västergötland. Upper Jonstorp Formation. RM Ar 6111. $\times 11$. C, pygidium from Bestorp, Mösseberg, Västergötland. Upper Jonstorp Formation. Latex cast from external mould. RM Ar 13660. $\times 10.3$. D, internal mould of a flattened pygidium from Kungslena, Varvsberget, Västergötland. Upper Jonstorp Formation. RM Ar 6122. ×10.2. E, pygidium with two incomplete thoracic tergites. Lasă, Bornholm, Denmark. Jerrestad Mudstone. Latex cast from external mould. Coll. S. L. Törnqvist. LO 5925t. ×8.4. F, pygidium and the posterior thoracic tergite. Kungslena, Varvsberget, Västergötland. Upper Jonstorp Formation. Coll. J. A. Wallin. Latex cast from external mould. LO 5926t. ×8.9. G, Incomplete pygidium from Kungslena, Varvsberget, Västergötland. Upper Jonstorp Formation. Coll. J. A. Wallin. Latex cast from external mould. LO 5927t. $\times 11.6$. H anterior thoracic tergite. Koängen in the Făgelsång area east of Lund, Scania. Jerrestad Mudstone. Coll. E. Olin 1899. LO 5928t. $\times 8.5$. I, meraspidid pygidium. Koängen in the Fảgelsăng area east of Lund, Scania. Jerrestad Mudstone. Coll. E. Olin 1899. LO 5929t. $\times 16$.

forms from the Caradoc-lower Ashgill of China are closely comparable to $A$. tarda. They differ from the type species mainly in having a longer glabella and pygidial rhachis. However, A. sinensis has a well-marked transglabellar furrow in front of the median node, and this species appears to be distinct from $A$. tarda.

Occurrence (Fig. 5). - Bornholm, Denmark: 


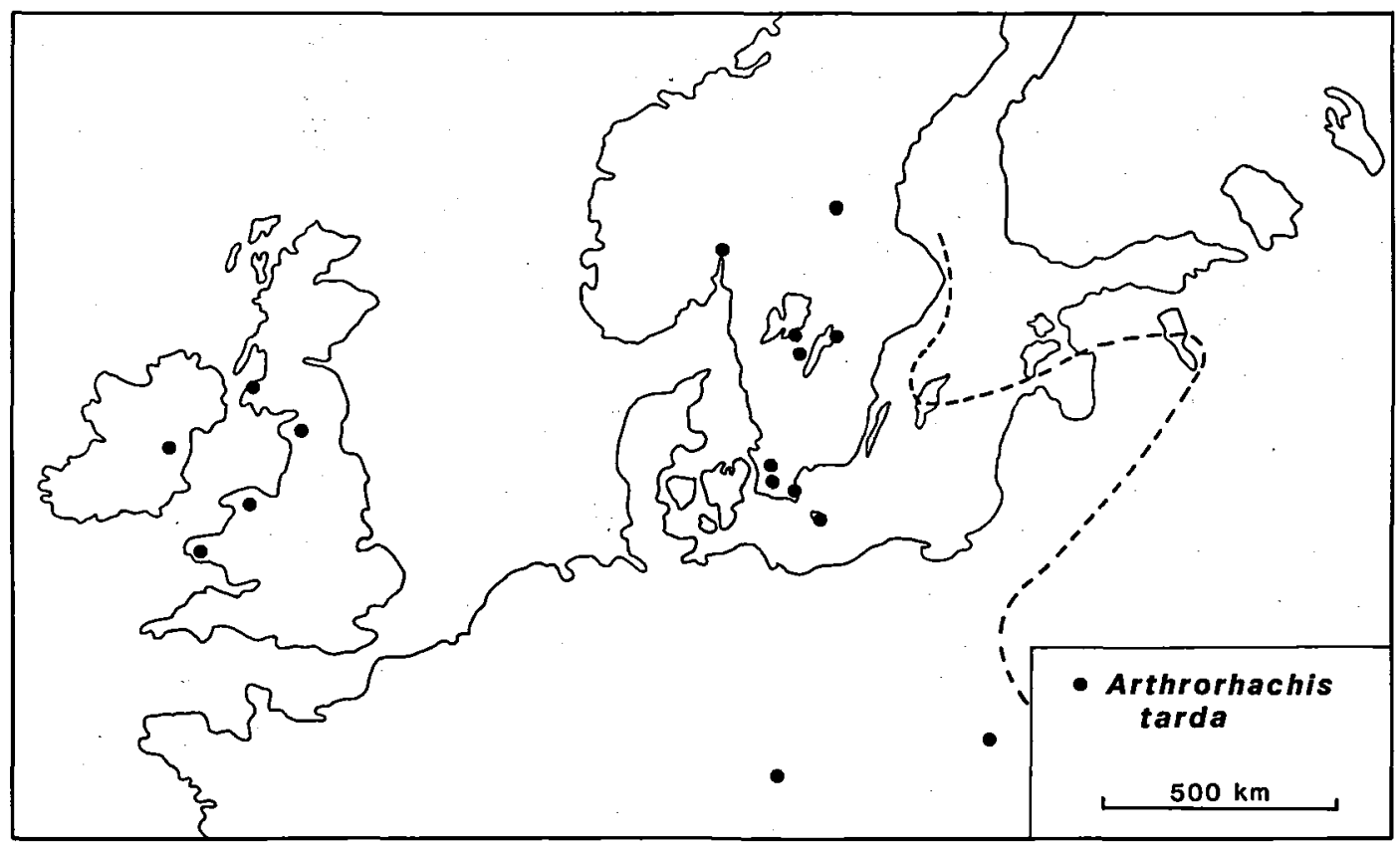

Fig. 5. Distribution of Arthrorhachis tarda (Barrande, 1846) in northern Europe. The western boundary of the North Estonian carbonate confacies belt is indicated by a dashed line. The distribution in Baltoscandia may suggest that it occupied relatively exterior sites on the Baltic palaeocontinent. The species has been recorded also from Kazakhstan and possibly Bukantau, Uzbekistan.

Læså (stream section at Vasegård; locality $3 \mathrm{C}$ of Gravesen \& Bjerreskov 1982:44); Øleå (stream section at Billegrav gård; Poulsen 1968); Risebæk (Ravn 1899; Kielan 1960, pl. 1, fig. 6).

Scania (Skåne), southern Sweden: Koängen in the classical Fågelsång area east of Lund (Olin 1906); Koängen core (Nilsson 1977); Lindegård core (Glimberg 1961); Röstånga (several localities; Olin 1906); Tommarp (several localities; Olin 1906); Jerrestad (stream section in the Jerrestadsån rivulet; Olin 1906); Tosterup (Olin 1906). In Scania and on Bornholm, Arthrorhachis tarda is restricted to the Jerrestad Mudstone Formation (Jerrestadian Stage).

Östergötland, south-central Sweden: Råssnäs and Rödbergsudden, both near Motala (see Törnquist 1875 and Jönsson 1887 for locality data). In addition to occurrences in the Upper Jonstorp Formation, a pygidium (RM Ar 15816) is known from the underlying Öglunda Limestone in the Råssnäs section.

In Västergötland, south-central Sweden, $A r$ throrhachis tarda is known from a great number of localities. The most important are the following (see Bergström 1968:3-4 for locality descrip- tions and references to most of them): Bestorp, Mösseberg; Stommen (Kungslena), Varvsberget; Skogastorp, Plantaberget (Högstenaberget); Skultorp, Billingen; Rustsäter, Kinnekulle; Kullatorp core, Kinnekulle (Wærn et al. 1948). Additional localities are listed by Linnarsson (1869:83). In Västergötland, $A$. tarda occurs frequently in the Upper Jonstorp Formation ("Red Tretaspis Shale") and Ulunda Mudstone of the upper Jerrestadian Stage. In the Bestorp section and Kullatorp core, however, it ranges down into the Lower Jonstorp Formation ("Green Tretaspis Shale"). In addition, a closely comparable and probably conspecific form is known from the Fjäcka Shale (Vasagaardian Stage) in the Kullatorp core (Wærn et al. 1948:377-378).

Dalarna, central Sweden: Vikarbyn and Gulleråsen-Sanden. The species is known solely from the Upper Jonstorp Formation.

Oslo Region, Norway: Hovedøya (Spannslokket Member of the Skogerholmen Formation; Owen 1981); Åslund, Hadeland (Gagnum Shale Member of the Lunner Formation; Owen 1981). In terms of the British sequence, the specimen from Hadeland is from the Pusgillian Stage, and 
the specimen from Hovedøya was recovered from the Rawtheyan Stage (see Owen 1981, textfig. 1 for stratigraphy).

The data above clearly show that Arthrorhachis tarda is a characteristic element of middle Ashgill trilobite faunas in Scandinavia, and that it is essentially restricted to mudstone units of the Jerrestadian Stage. In Västergötland, south-central Sweden, and in Norway, however, it appears to range down into the lower Ashgill (Vasagaardian Stage).

Outside Scandinavia, Arthrorhachis tarda has been recorded from a number of localities in Poland (Kielan 1960), Bohemia (Pek 1977), the British Isles (Whittington 1968; Ingham 1970; Dean 1971), and Kazakhstan (Apollonov 1974). In Bohemia, it has been recovered both from the lower and upper part of the Ashgillian Králúv Dvur Formation. The Polish specimens are mainly from strata corresponding to the Jerrestadian Stage of Baltoscandia. In addition, Kielan (1960) reported the species from strata yielding among others Dalmanitina mucronata (Brongniart, 1822), Brongniartella platynota (Dalman, 1828), Leonaspis olini (Troedsson, 1918), and Phillipsinella parabola (Barrande, 1846). These strata, designated as Dalmanitina beds by Kielan (1960), may be of Hirnantian age (cf. Owen 1986, table 2). However, Dalmanitina mucronata and several of the associated trilobites appear already in the Jerrestadian Stage, and it may be difficult to distinguish between the lower Dalmanitina beds and the Staurocephalus clavifrons Zone of the upper Jerrestadian Stage (e.g. Nilsson 1979). Thus, a Hirnantian age for Arthrorhachis tarda in the Dalmanitina beds of Poland cannot be corroborated.

In the British Isles, most occurrences of $\mathrm{Ar}$ throrhachis tarda are within the Rawtheyan Stage. There are, however, also rare occurrences in the Cautleyan Stage of Haverfordwest, South Wales (Sholeshook Limestone; Dean 1971). In addition, there is a record of the species from the Whitehouse Group (Caradoc-Ashgill transition) of the Girvan district, Scotland (Reed 1903:7-8, pl. 1, figs. 8-9). However, the Whitehouse specimens have not been properly illustrated and need to be revised, and I cannot determine whether they belong to $A$. tarda or to a closely related species.

In conclusion, Arthrorhachis tarda appears to range almost throughout the entire pre-Hirnantian Ashgill, but most of its occurrences are in middle Ashgill units (Jerrestadian Stage of Baltoscandia; Cautleyan and Rawtheyan Stages of the British Isles).

Family Sphaeragnostidae Kobayashi, 1939

Genus Sphaeragnostus Howell \& Resser (in Cooper \& Kindle 1936)

Type species. - Agnostus similaris Barrande, 1872 (pp. 144-145, pl. 14, figs. 17-18) from the Dobrotivá Formation (Llandeilo) of central Bohemia; by original designation.

Emended diagnosis. - The cephalon is highly effaced, nearly featureless, and subelliptical in outline, with a length (sag.) slightly greater than the maximum width. It is evenly vaulted and lacks a border. The posterior margin is nearly straight. A weak median node is generally present.

The pygidium is of similar outline and convexity to the cephalon. The rhachis is well defined, convex, subcircular in outline, and nearly featureless except for one or two faint median nodes. The pleural fields are smooth, generally widest sagittally, and slope laterally and posteriorly. The posterior and lateral border is well defined, without spines, and generally widest sagittally, narrowing gradually towards the anterolateral corners.

Species included. - Agnostus similaris Barrande, 1872 from the Llandeilo (Dobrotivá Formation) of Bohemia; Agnostus cingulatus Olin, 1906 (pp. 72-73, pl. 4, fig. 17) from the Upper Ordovician (Jerrestad Mudstone Formation) of Scania, southern Sweden; Sphaeragnostus gaspensis Cooper \& Kindle, 1936 (p. 361, pl. 52, figs. 15, $17,22,23,35)$ from the Upper Ordovician (Grande Coupe beds of Lespérance et al. 1987) of Percé, Quebec, Canada; Sphaeragnostus cerus Zhou (in Lu et al. 1976:59-60, pl. 9, fig. 4) from the lower Ashgill of Jiangxi and western Zhejiang, China; Sphaeragnostus nudatus Koroleva 1982 (pp. 36-37, pl. 2, fig. 8) from the Caradoc (lower Majlisor horizon) of Kazakhstan; Sphaeragnostus subcircularis Zhou (in Zhou et al. 1982:218-219, pl. 57, fig. 13) from the CaradocAshgill of Subei, Gansu, China. 

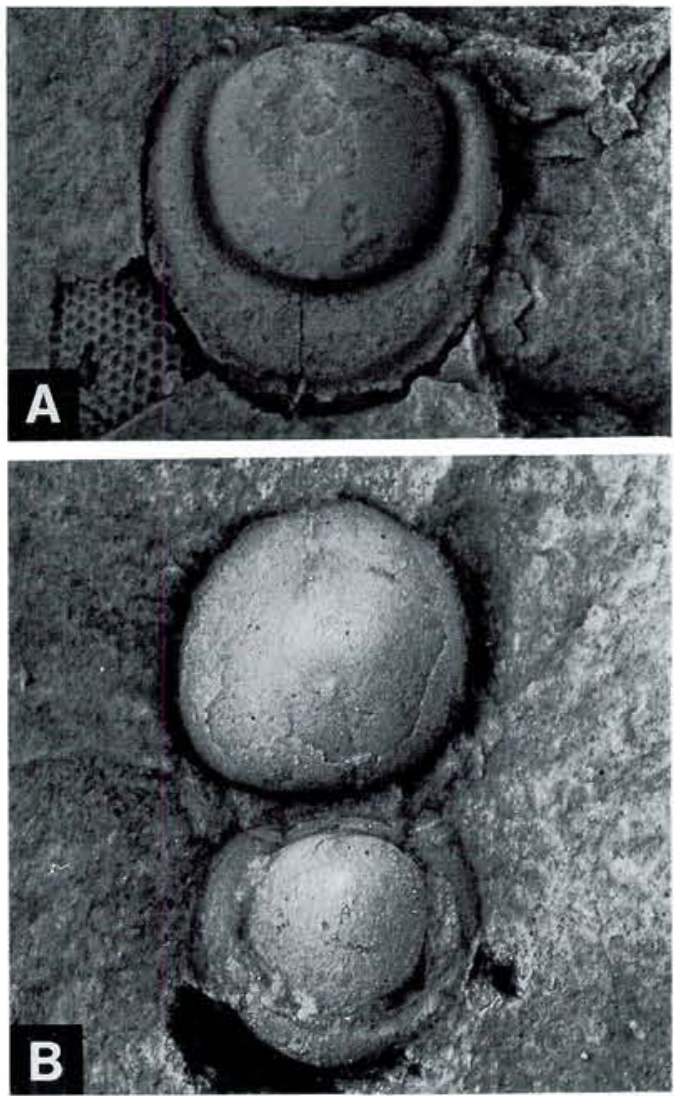

Fig. 6. Sphaeragnostus cingulatus (Olin, 1906) from the Jerrestad Mudstone (middle Upper Ordovician; Jerrestadian Stage). A, holotype, an internal mould of a nearly complete pygidium from Koängen in the classical Făgelsång area east of Lund, Scania, southern Sweden. Figured by Olin (1906, pl. 4, fig. 17). LO 1981 T. $\times 7.3$. B, a nearly complete but poorly preserved specimen from a stream-section at Vasegård, Læså, Bornholm, Denmark. MGUH 1930.104. ×7.2

Remarks. - Effacement is a common evolutionary trend in several lineages of agnostid trilobites, resulting in multiple, smooth homeomorphs that are difficult to distinguish. Cephala of species referred to Sphaeragnostus are characterized by extreme effacement of the furrows and lobes, and they are very like those of the Ordovician Leiagnostus species. Pygidia of Sphaeragnostus are distinctive, however, and differ from those of Leiagnostus and other highly effaced genera in having a smooth but easily recognizable rhachis which is subcircular in outline.

Sphaeragnostus is difficult to relate to any noneffaced agnostids, and the systematic affinity of the genus is obscure.
Distribution. - Llanvirn-Ashgill; Bohemia (Pek 1977), southern Scandinavia (Olin 1906; Kielan 1960), Poland (Kielan 1960), Scotland (Thomas et al. 1984:40), Wales (Thomas et al. 1984:45), Quebec (Cooper \& Kindle 1936; Robison 1987, fig. 13.24J-L), Kazakhstan (Koroleva 1982), China (Zhou 1987).

To the occurrences listed above may be added western Ireland, if Weir's (1959, pl. 63, figs. 9a-b) specimen of an agnostid trilobite from the Ashgillian Ballyvorgal Group of Clare is interpreted as a pygidium of Sphaeragnostus (cf. Whittington 1968:121).

\section{Sphaeragnostus cingulatus (Olin, 1906)}

Fig. 6A-B

1906 Agnostus cingulatus n.sp. - Olin, pp. 72-73, pl. 4, fig. 17.

1960 Sphaeragnostus cingulatus (Olin, 1906) Kielan, p. 57.

1960 Sphaeragnostus gaspensis europeensis n.subsp. - Kielan, pp. 56-57, text-fig. 11, pl. 1, figs. 1-3.

?1976 Sphaeragnostus cerus Zhou (sp.nov.) Zhou in Lu et al., pp. 59-60, pl. 9, fig. 4.

?1982 Sphaeragnostus subcircularis zhou (sp. nov.) - Zhou in Zhou et al., pp. 218-219, pl. 57, fig. 13 .

Holotype. - By monotypy, an internal mould of a nearly complete pygidium (LO 1981T; Fig. 6A), collected by Emil Olin in 1899.

Material. - In addition to the holotype, a nearly complete but poorly preserved specimen from Bornholm, Denmark (Fig. 6B), and an internal mould of a pygidium from the Lindegård core no. 28 , Scania, Sweden.

Description. - The cephalon is highly effaced and subelliptical in outline with a length (sag.) slightly greater than the width. It is evenly vaulted, widest at about mid-length, and lacks a border. A minute median node is faintly indicated and situated at approximately one-third of the cephalic length from the posterior margin.

The pygidium is subcircular to subelliptical in outline, subequal in length and width, and evenly rounded posteriorly. It is moderately convex and widest along a transverse line slightly anterior to 
Table 3. Dimensions (in mm) of the holotype of Sphaeragnostus cingulatus.

\begin{tabular}{lccccccc}
\hline & Lp1 & Lp2 & Lr & Lbp & Wp & Wr \\
\hline LO 1981T & - & 5.3 & 3.3 & 0.5 & 5.2 & 3.3 \\
\hline
\end{tabular}

the mid-length. The pygidial rhachis, occupying about $62 \%$ of the total pygidial length (excl. the articulating half-ring) in the holotype, is subcircular in outline, about as long as it is wide, and nearly featureless. It is highly convex and delimited by deeply incised dorsal furrows. In the pygidia from Scania, a minute node is faintly indicated at the posterior end of the rhachis. The pygidium from Bornholm shows that there is a median node in the anterior portion of the rhachis. The pleural fields are smooth, convex, widest sagittally, and slope appreciably laterally and posteriorly. The border, occupying about $10 \%$ of the total pygidial length, is poorly preserved but obviously becomes narrower anteriorly towards the antero-lateral corners. It appears to be defined mainly by an abrupt change in slope. The anterior border and articulating halfring are not preserved.

The dimensions of the holotype are given in table 3.

Remarks. - Sphaeragnostus gaspensis europeensis Kielan, 1960 from the Staurocephalus clavifrons Zone of Poland appears to differ from $S$. cingulatus only in being slightly more elongate (length of pygidium nearly 1.3 times its width). This difference may be due to distortion or intraspecific morphological variability, and is not here considered to be of taxonomic significance. Therefore, $S$. gaspensis europeensis is considered to be conspecific with $S$. cingulatus.

Sphaeragnostus subcircularis Zhou (in Zhou et al. 1982) from the Caradoc-Ashgill of China is very similar to $S$. cingulatus and may eventually prove to be a junior subjective synonym of the latter. A similar uncertainty affects the validity of $S$. cerus Zhou (in $\mathrm{Lu}$ et al. 1976) from the lower Ashgill of eastern China.

Sphaeragnostus gaspensis Cooper \& Kindle, 1936 from the Upper Ordovician of the Percé area, Quebec, Canada, and $S$. cingulatus are exceedingly alike, and the former differs from the latter mainly in having a more elongate pygidium (width/length ratio about 1:1.2) and a more ante- riorly situated median node on the cephalon (at mid-length). In addition, $S$. gaspensis appears to lack a node at the posterior end of the rhachis, but this may be because it is covered with the exoskeleton.

Occurrence. - Middle Upper Ordovician (Jerrestadian Stage). Koängen, Scania, southern Sweden (Jerrestad Mudstone; locality described by Olin 1906:19); Lindegård (S. Sandby) core no. 28 (depth 21.41-21.65 m; Jerrestad Mudstone), east of Lund, western Scania; stream-section at Vasegård, Laså, Bornholm, Denmark (Jerrestad Mudstone; locality $3 \mathrm{C}$ of Gravesen \& Bjerreskov 1982:44); Brzezinki, Poland (Staurocephalus clavifrons Zone).

\section{Concluding remarks}

Epicontinental Upper Ordovician rocks crop out in a great number of areas in northern Europe. The sequences are generally richly fossiliferous and studies during the last decades have revealed a complexity in the distribution patterns of trilobites and brachiopods. Jaanusson (1979) summarized the faunal distribution data for northern Europe, and distinguished between three spatially different lower and middle Ashgillian faunas:

(1) Faunas of Mediterranean (Bohemian) type characterize sequences that consist predominantly of mudstone. Trilobites are numerically dominating and they have a high taxonomic diversity. Faunas of Mediterranean affinities are generally characterized by the occurrence of the trilobite genus Phillipsinella, and they are widespread in Bohemia, Poland, southern Scandinavia, and the British Isles (Jaanusson 1979, fig. 10).

(2) Hiberno-Salairian faunas are confined mostly to limestones associated with mudstone. The macrofauna is rich and diverse, but generally oc- 
curs in patches. The trilobite genus Holotrachelus is a characteristic element. A typical example of limestones with a Hiberno-Salairian fauna is the Upper Ordovician Boda Limestone of the Siljan district in Sweden. Where the limestones intergrade with the mudstones, as in Ireland and in parts of northern England, the Hiberno-Salairian faunas are mingled with Mediterranean elements.

(3) Faunas of the North Estonian carbonate confacies belt. The trilobites have a low diversity, generally with Chasmops (Toxochasmops) as a distinctive genus.

In Bohemia, Poland and southern Scandinavia, Arthrorhachis tarda is generally associated with Phillipsinella parabola (Barrande, 1846) and mostly confined to fine-grained terrigenous sediments. Neither of these species has been recorded from the North Estonian carbonate confacies belt or from the Boda Limestone (carbonate mounds) of the Siljan district in Sweden. In the British Isles, $A$. tarda is widely distributed, especially in the Rawtheyan Stage, and it is frequently encountered in mudstones yielding Phillipsinella (e.g. Whittington 1968, table 4; Dean 1978: 111112). Thus, the distributional data of Arthrorhachis tarda suggest that it is a typical component of faunas with Mediterranean affinities. It must be emphasized, however, that $A$. tarda is also known from reefal limestones with Hiberno-Salairian faunas in eastern Ireland (Chair of Kildare Limestone; Dean 1971) and in northern England (Keisley Limestone; Dean 1971). However, the faunas of these limestones have also yielded Phillipsinella parabola and they appear to be mingled with Mediterranean elements.

Sphaeragnostus cingulatus and closely comparable Ashgillian forms of Europe are associated with mudstones, and, although rare, they seem to represent elements of Mediterranean-type faunas. Similar faunas from the Ashgillian Grande Coupe beds of the Percé area in Quebec have yielded the closely allied species $S$. gaspensis, and they show a striking affinity with northwestern European faunas (Lespérance 1968; Lespérance et al. 1987:125).

Evidence presented by Jaanusson (1979) strongly suggests that the distribution of many elements of the Mediterranean-type faunas are related to lithofacies, and they appear to have been basically substrate-dependent (cf. Jaanusson 1984:136). Arthrorhachis tarda is clearly a common element of the Mediterranean-type faunas and generally associated with mudstones. This may suggest that it is related to benthic conditions and a benthic habitat may seem likely (cf. Fortey \& Barnes 1977:306). A pelagic mode of life cannot be excluded, however, because the distribution may well have been controlled by other environmental factors which also influence the sedimentation. Thus, a strong positive correlation between certain agnostid trilobites and facies type is not necessarily in conflict with a supposed swimming or floating mode of life for agnostid trilobites.

Acknowledgements. Professor Valdar Jaanusson (Stockholm) critically read the draft of the manuscript and suggested valuable improvements. BSc Karin Ryde (Lund) kindly corrected the English. Mr Rezsö Laszlo (Lund) skillfully carried out the dark-room work, and Mrs Bitten Arvidson (Lund) made the drawings. Financial support has been received from the Swedish Natural Science Research Council (NFR).

\section{Dansk sammendrag}

Fra Skandinaviens øvre ordovicium (Harju Serien) kendes for indeværende kun 2 arter af agnostide trilobiter, Sphaeragnostus cingulatus (Olin, 1906) og Arthrorhachis tarda (Barrande, 1846). Af disse er $S$. cingulatus uhyre sjælden og kendes i Skandinavien kun fra Jerrestad Formationen (mellemste ashgill) på Bornholm og i Skåne; definitionen af slægten Sphaeragnostus er revideret. $A$. tarda er derimod ret hyppig i Jonstorp Formationen (mellemste ashgill) og jævnaldrende enheder, og kendes fra en lang række lokaliteter i det sydlige og syd-centrale Skandinavien. Uden for Skandinavien er $A$. tarda almindelig kendt fra det øverste ordovicium i Polen, Böhmen, Kazakhstan og forskellige egne af Storbritannien. I de fleste af disse områder er arten overvejende begrænset til mudderstens-sekvenser, og den er normalt associeret med faunaer af "mediterran type". A. tarda synes at optræde gennem hele ashgill med undtagelse af hirnantian, men den er mest almindelig $i$ enheder fra mellemste ashgill. 


\section{References}

Abdullaev, R. N. 1972: Trilobity verkhnego ordovika Bukantau. [Upper Ordovician trilobites of Bukantau.] In Novye dannye po faune paleozoya i mezozoya Uzbekistana, 103126. Akad. Nauk Uzbek. SSR, Inst. Geol. Geofiz., Tashkent.

Angelin, N.P. 1851: Palaeontologia Svecica. I: Iconographia crustaceorum formationis transitionis. Fasc. 1. 1-24. Lund.

Apollonov, M. K. 1974: Ashgillskie trilobity Kazakhstana. [Ashgillian trilobites of Kazakhstan.] 136 pp. Akad. Nauk Kazakh. SSR, Inst. Geol. Nauk. Alma-Ata. [In Russian.]

Barrande, J. 1846: Notice préliminare sur le Systême silurien et les Trilobites de Bohême. vi $+97 \mathrm{pp}$. Leipsic.

Barrande, J. 1852: Systême Silurien du centre de la Bohême. lère Partie: Recherches Paleontologiques, I (Crustacés: Trilobites). 935 pp. Prague and Paris.

Barrande, J. 1872: Systême Silurien du centre de la Bohême. lère Partie: Recherches Paléontologiques. Supplément au Vol. 1. Trilobites, Crustacés divers et Poissons. 647 pp. Prague and Paris.

Bergström, J. 1968: Upper Ordovician brachiopods from Västergötland, Sweden. Geol. et Palaeontol. 2, 1-35.

Bruton, D. L. \& Owen, A. W. 1979: Late Caradoc-early Ashgill trilobite distribution in the central Oslo Region, Norway. Norsk Geol. Tidsskr. 59, 213-222.

Bruton, D. L. \& Williams, S.H. (eds.) 1982: Field excursion guide. IV International Symposium on the Ordovician System. Paleont. Contr. Univ. Oslo 279, 1-217.

Cooper, G. A. \& Kindle, C. H. 1936: New brachiopods and trilobites from the Upper Ordovician of Percé, Quebec. $J$. Paleont. 10, 348-372.

Dean, W. T. 1971: The trilobites of the Chair of Kildare Limestone (Upper Ordovician) of eastern Ireland. 1. Palaeontogr. Soc. [Monogr.], 1-60.

Dean, W. T. 1978: The trilobites of the Chair of Kildare Limestone (Upper Ordovician) of eastern Ireland. 3. Palaeontogr. Soc. [Monogr.], 99-129.

Fortey, R. A. 1980: The Ordovician trilobites of Spitsbergen. III. Remaining trilobites of the Valhallfonna Formation. Nor. Polarinst., Skr. 171, 1-163.

Fortey, R. A. \& Barnes, C. R. 1977: Early Ordovician conodont and trilobite communities of Spitsbergen: influence on biogeography. Alcheringa 1, 297-309.

Glimberg, C. F. 1961: Middle and Upper Ordovician strata at Lindegård in the Fågelsång district, Scania, S. Sweden. Geol. Fören. Stockholm Förh. 83, 79-85.

Gravesen, P. \& Bjerreskov, M. 1982: Guide to excursions in Bornholm during the 8th annual working meeting in Sweden and Denmark of Project Tornquist - Southwest border of the East-European Platform (IGCP Project No. 86). 84 pp. Geological Survey of Denmark, Copenhagen.

Hawle, J. \& Corda, A. J. C. 1847: Prodrom einer Monographie der böhmischen Trilobiten. 176 pp. J. G. Calve, Prague.

Holmer, L. E. 1986: Inarticulate brachiopods around the Middle-Upper Ordovician boundary in Västergötland. Geol. Fören. Stockholm Förh. 108, 97-126.

Horny, R. \& Bastl, F. 1970: Type Specimens of Fossils in the National Museum Praque. Volume 1: Trilobita. $354 \mathrm{pp}$. Museum of Natural History, Prague.

Hunt, A. S. 1967: Growth, variation, and instar development of an agnostid trilobite. J. Paleont. 41, 203-208.

Ingham, J. K. 1970: The Upper Ordovician trilobites from the Cautley and Dent districts of Westmorland and Yorkshire. 1. Palaeontogr. Soc. [Monogr.], 1-58.

Jaanusson, V. 1963: Classification of the Harjuan (Upper Ordovician) rocks of the mainland of Sweden. Geol. Fören. Stockholm Förh. 85, 110-144.

Jaanusson, V. 1979: Ordovician. In Robison, R. A. \& Teichert,
C. (eds.): Treatise on Invertebrate paleontology, Part A, Intraduction, A136-A167. Geol. Soc. Am. and Univ. Kansas Press.

Jaanusson, V. 1984: Ordovician benthic macrofaunal associations. In Bruton, D. L. (ed.): Aspects of the Ordovician System. Palaeont. Contr. Univ. Oslo 295, 127-139.

Jaekel, O. 1909: Über die Agnostiden. Z. dtsch. geol. Ges. 61, 380-401.

Jönsson, J. 1887: Beskrifning till kartbladet Motala. Sver. geol. Unders. Aa 102, 1-43.

Kielan, Z. 1956: Stratygrafia górnego ordowiku w Górach Swietokrzyskich (On the stratigraphy of the Upper Ordovician in the Holy Cross Mts.). Acta Geol. Polon. 6, 253271. [In Polish with English summary.]

Kielan, Z. 1960: Upper Ordovician trilobites from Poland and some related forms from Bohemia and Scandinavia. Palaeont. Polon. 11, 1-198.

Kobayashi, T. 1939: On the agnostids (Part I). J. Fac. Sci. Imp. Univ. Tokyo, sect. 2, 5(5), 70-198.

Koliha, J. 1922: Přispěvek ku poznání rodu Agnostus. Vẽda prír. A III, 1-6.

Koroleva, M.N. 1982: Trilobity ordovika severo-vostochnogo Kazakhstana. [Ordovician trilobites of north-east Kazakhstan.] 192 pp. Nedra, Moscow. [In Russian.]

Lespérance, P. J. 1968: Faunal affinities of the trilobite faunas, White Head Formation, Percé region, Quebec, Canada. Int. Geol. Congr., 23rd Session, Section 9, 145-159. Prague.

Lespérance, P. J., Malo, M., Sheehan, P. M. \& Skidmore, W. B. 1987: A stratigraphical and faunal revision of the Ordovician-Silurian strata of the Percé area, Quebec. Can. J. Earth Sci. 24, 117-134.

Linnarsson, G. 1869: Om Vestergötlands cambriska och siluriska aflagringar. K. svenska Vetensk.-Akad. Handl. 8(2), $1-89$.

Lu Yanhao, Chu Chaoling, Chien Yiyuan, Zhou Zhiyi, Chen Junyuan, Liu Gengwu, Yu Wen, Chen Xu \& Xu Hankui 1976: Ordovician biostratigraphy and palaeozoogeography of China. Mem. Nanjing Inst. Geol. Palaeont. 7, 1-83. [In Chinese.]

M'Coy, F. in Sedgwick, A. \& M'Coy, F. 1851-1855: A synopsis of the classification of the British Palaeozoic rocks, with a systematic description of the British Palaeozoic fossils in the geological museum of the University of Cambridge. Fasc. I, $1-184,1851$; fasc. II, 185-406, 1852; fasc. III, 407-661, 1855. London and Cambridge.

Nilsson, R. 1977: A boring through Middle and Upper Ordovician strata at Koängen in western Scania, southern Sweden. Sver. geol. Unders. C733, 1-58.

Nilsson, R. 1979: A boring through the Ordovician-Silurian boundary in western Scania, south Sweden. Sver. geol. Unders. C766, 1-18.

Olin, E. 1906: On de chasmopskalken och trinucleusskiffern motsvarande bildningarne i Skåne. Lunds Univ. Ärsskr. N.F. Afd. 2, 2(3), 1-79.

Owen, A. W. 1981: the Ashgill trilobites of the Oslo Region, Norway. Palaeontographica Abt. A 175, 1-88.

Owen, A. W. 1986: The uppermost Ordovician (Hirnantian) trilobites of Girvan, SW Scotland with a review of coeval trilobite faunas. Trans. R. Soc. Edinburgh: Earth Sci. 77, 231-239.

Owen, A. W. \& Bruton, D. L. 1980: Late Caradoc-early Ashgill trilobites of the central Oslo Region, Norway. Paleont. Contr. Univ. Oslo 245, 1-42.

Pek, I. 1977: Agnostid trilobites of the Central Bohemian Ordovician. Sb. geol. ved, paleont. 19, 7-44.

Poulsen, V. 1968: Tretaspis Shale at Øleå Bornholm. Meddr dansk geol. Foren. 18, 349-350.

Ravn, J. P. J. 1899: Trilobitfaunaen i den bornholmske Trinucleusskifer. Danm. geol. Unders. II 10, 49-60. 
Reed, F. R. C. 1896: The fauna of the Keisley Limestone. Part I. Quart. J. Geol. Soc. London 52, 407-437.

Reed, F. R.C. 1903: The Lower Palaeozoic trilobites of the Girvan district, Ayrshire. Palaeontogr. Soc. [Monogr.], $1-48$.

Robison, R. A 1982: Some Middle Cambrian agnostoid trilobites from western North America. J. Paleont. 56, 132160.

Robison, R.A. 1987: Superclass Trilobitomorpha. In Boardman, R.S., Cheetham, A. H. \& Rowell, A. J. (eds.): Fossil Invertebrates 221-241. Blackwell Scientific Publications.

Salter, J. W, 1864: Figures and descriptions illustrative of British organic remains. Mem. geol. Surv. U.K., Dec. 11. 54 $\mathrm{pp}$.

Sheng, S.F. 1964: Upper Ordovician trilobite faunas of Szechuan-Kweichow with special discussion on the classification and boundaries of the Upper Ordovician. Acta Palaeont. Sinica 12, 537-563. [In Chinese with English summary.]

Snajdr, M. 1983: Revision of the trilobite type material of $I$. Hawle and A. J. C. Corda, 1847. Sb. Nár. Muz. v Praze B39(3), 129-212.

Thomas, A. T., Owens R. M. \& Rushton, A. W. A. 1984: Trilobites in British stratigraphy. Geol. Soc. London, Spec. Rep. 16, 1-78.
Törnquist, S. L. 1875: Berättelse om en geologisk resa genom Skånes och Östergötlands paleozoiska trakter, sommaren 1875. Öfvers. K. Vetensk.-Akad. Förh. 1875(10), 43-70.

Wærn, B., Thorslund, P. \& Henningsmoen, G. 1948: Deep boring through Ordovician and Silurian strata at Kinnekulle, Vestergötland. Bull. Geol. Inst. Univ. Uppsala 32, 337-474.

Weir, J. A. 1959: Ashgillian trilobites from Co. Clare, Ireland. Palaeontology 1, 369-383.

Whittington, H. B. 1950: Sixteen Ordovician genotype trilobites. J. Paleont. 24, 531-565.

Whittington, H.B. 1963: Middle Ordovician trilobites from Lower Head, western Newfoundland. Bull. Mus. Comp. Zool. 129, 1-118.

Whittington, H. B. 1968: The Ordovician trilobites of the Bala area, Merioneth. IV. Palaeontogr. Soc. [ Monogr.], 93138.

Zhou Zhiqiang, Lee Jingsen \& Qu Xingguo 1982: Trilobita. In Paleontological Atlas of northwest China: Shaanxi, Gansu and Ningxia Volume, Part I, Precambrian and Early Paleozoic, 215-294. Geological Publishing House, Beijing. [In Chinese.]

Zhou Zhi-yi 1987: Notes on Chinese Ordovician agnostids. Acta Palaeont. Sinica 26, 639-661. [In Chinese with English summary.] 